\title{
Three-Dimensional Geologic Framework Model for a Karst Aquifer System, Hasty and Western Grove Quadrangles, Northern Arkansas
}

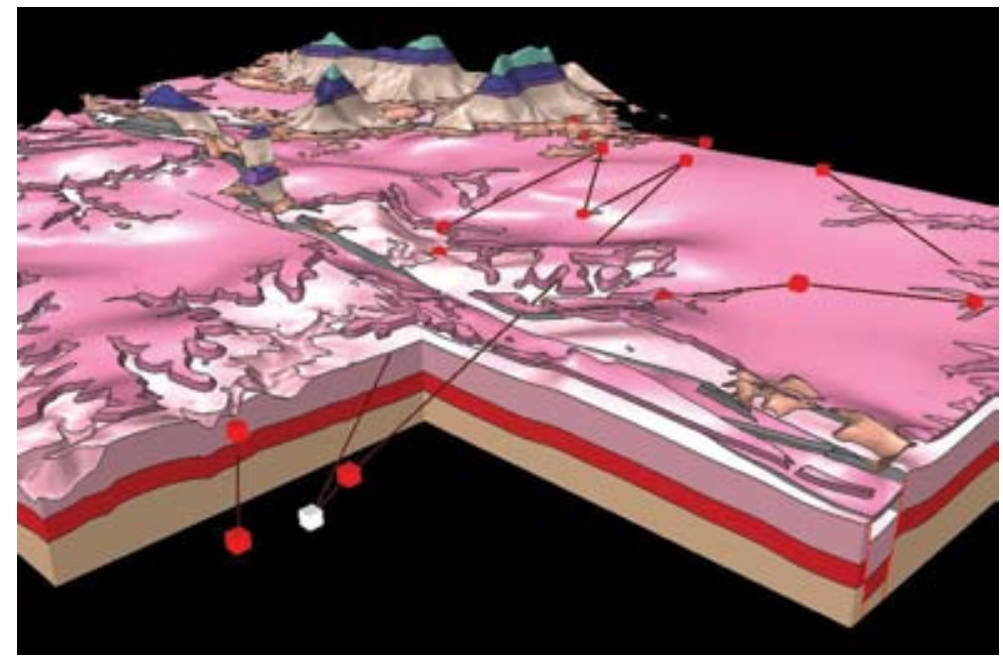

Scientific Investigations Report 2007-5095 


\section{Three-Dimensional Geologic Framework Model for a Karst Aquifer System, Hasty and Western Grove Quadrangles, Northern Arkansas}

By Kenzie J. Turner, Mark R. Hudson, Kyle E. Murray, and David N. Mott

Prepared in cooperation with the

National Park Service

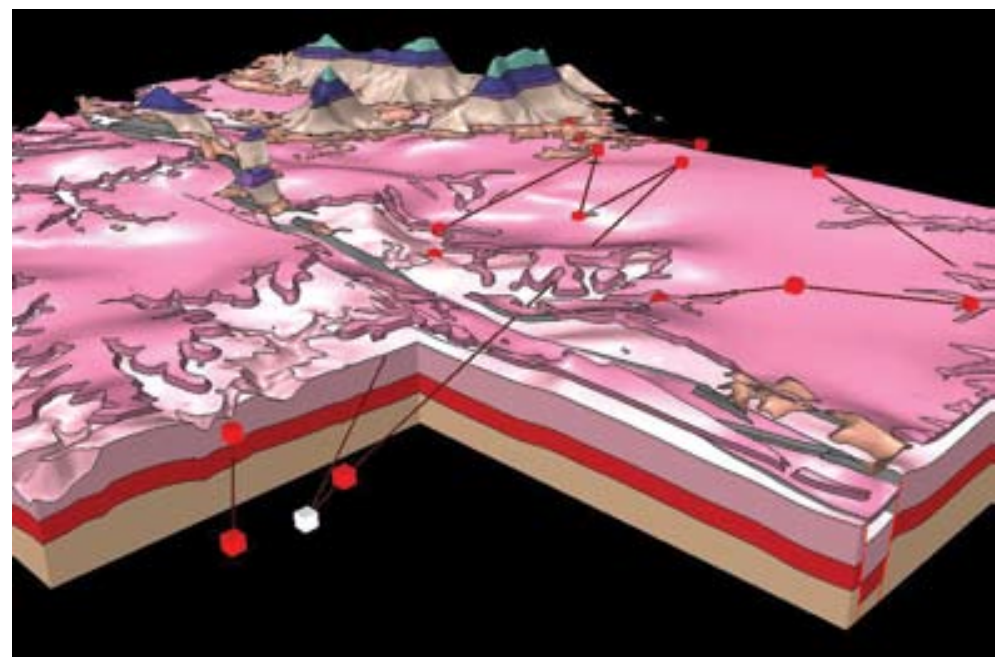

Scientific Investigations Report 2007-5095 


\title{
U.S. Department of the Interior DIRK KEMPTHORNE, Secretary
}

\author{
U.S. Geological Survey \\ Mark D. Myers, Director
}

\section{U.S. Geological Survey, Reston, Virginia: 2007}

For sale by U.S. Geological Survey, Information Services

Box 25286, Denver Federal Center Denver, CO 80225

For more information about the USGS and its products:

Telephone: 1-888-ASK-USGS

World Wide Web: http://www.usgs.gov/

Any use of trade, product, or firm names in this publication is for descriptive purposes only and does not imply endorsement by the U.S. Government.

Although this report is in the public domain, permission must be secured from the individual copyright owners to reproduce any copyrighted materials contained within this report.

Suggested citation:

Turner, K.J., Hudson, M.R., Murray, K.E., and Mott, D.N., 2007, Three-Dimensional Geologic

Framework Model for a Karst Aquifer System, Hasty and Western Grove Quadrangles, Northern Arkansas: U.S. Geological Survey Scientific Investigations Report 2007-5095, 12 p. 


\section{Contents}

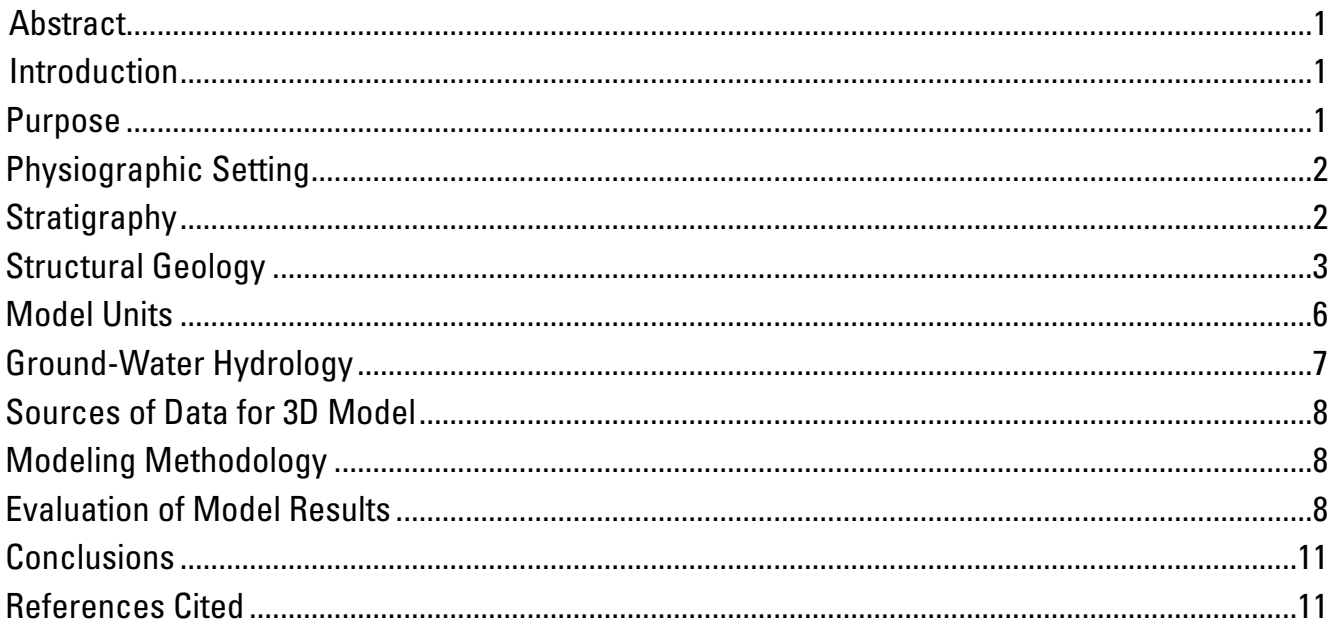

\section{Figures}

1. Location of model area in and adjacent to the Buffalo National River in northern Arkansas. Lower regional map illustrates location of the model area relative to other tectonic provinces.

2. Stratigraphic section showing approximate thickness, lithology, and system of formations within the model area. The exposed lithologies start approximately at the unconformable contact between the Everton Formation and the Powell Dolomite. The aquifers of interest in this report are highlighted in yellow.

3. Area map showing generalized geology, structure contours, structural features, Davis Creek watershed, and key geographic features (geology from Hudson and Murray (2004) and Hudson and others (2006).

4. Expression of structural features in the modeled Cotter Dolomite horizon. Gray area through the center of the image is the down-dropped Mill Creek graben. $V i e w$ is looking directly north. Values along front edge of image are in meters but the scale varies to the north. Vertical exaggeration is about $2 \mathrm{X}$.

5. Portion of the Davis Creek Subbasin. The white line indicates the surface water shed topographic boundary. Symbology for dye injection sites and spring/dye receptor sites follows that described in fig. 3 . Arrows point from input to discharge locations. Geology from 3D model, as in fig. 6 .

6. Comparison of geology from the 3D model (top) and published mapping (bottom) by Hudson and Murray (2004) and Hudson and others (2006). White arrows indicate an area where the modeled geology differs from the published geology and is discussed in the text. Published mapping includes surficial units whereas the image from the model does not. Definition of unit abbreviations follows those used in figs. 2 and 3 .

7. Cross-section comparison between $A$ (top), published Western Grove crosssection from Hudson and others (2006) and B (bottom), cross-section generated from the 3D model. For definition of map-unit symbols see fig. 2. No color represents the Cotter Dolomite in the top cross-section because Hudson and others (2006) did not include it. 


\section{Conversion Factors, Vertical Datum and Acronyms}

\begin{tabular}{lcl}
\hline Multiply & $\begin{array}{c}\text { By } \\
\text { Length }\end{array}$ & \multicolumn{1}{c}{ To obtain } \\
\hline foot $(\mathrm{ft})$ & 0.3048 & meter $(\mathrm{m})$ \\
$\operatorname{meter}(\mathrm{m})$ & 1.609 & kilometer $(\mathrm{km})$ \\
\hline
\end{tabular}

Vertical coordinate information is referenced to the National Geodetic Vertical Datum of 1929 (NGVD 29).

Horizontal coordinate information is referenced to the North American Datum of 1927 (NAD 27).

Altitude, as used in this report, refers to distance above the vertical datum.

\section{Acronyms}

GPS Global Positioning System

UTM Universal Transverse Mercator

GIS Geographic Information System

DEM Digital Elevation Model

DGI Dynamic Graphics, Inc. 


\title{
Three-Dimensional Geologic Framework Model for a Karst Aquifer System, Hasty and Western Grove Quadrangles, Northern Arkansas
}

\author{
By Kenzie J. Turner, ${ }^{1}$ Mark R. Hudson ${ }^{1}$ Kyle E. Murray, ${ }^{2}$ and David N. Mott ${ }^{3}$
}

\begin{abstract}
Understanding ground-water flow in a karst aquifer benefits from a detailed conception of the three-dimensional (3D) geologic framework. Traditional two-dimensional products, such as geologic maps, cross-sections, and structure contour maps, convey a mental picture of the area but a stronger conceptualization can be achieved by constructing a digital 3D representation of the stratigraphic and structural geologic features. In this study, a 3D geologic model was created to better understand a karst aquifer system in the Buffalo National River watershed in northern Arkansas. The model was constructed based on data obtained from recent, detailed geologic mapping for the Hasty and Western Grove 7.5-minute quadrangles. The resulting model represents 11 stratigraphic zones of Ordovician, Mississippian, and Pennsylvanian age. As a result of the highly dissected topography, stratigraphic and structural control from geologic contacts and interpreted structure contours were sufficient for effectively modeling the faults and folds in the model area. Combined with recent dye-tracing studies, the 3D framework model is useful for visualizing the various geologic features and for analyzing the potential control they exert on the ground-water flow regime. Evaluation of the model, by comparison to published maps and cross-sections, indicates that the model accurately reproduces both the surface geology and subsurface geologic features of the area.
\end{abstract}

\section{Introduction}

The Buffalo National River, located in northern Arkansas, was established as a national park in 1972 because it is one of America's few remaining undammed rivers over $150 \mathrm{mi}$ (241 $\mathrm{km}$ ) in length (Mott and others, 1999). The 130-mi- (209 km)

\footnotetext{
${ }^{1}$ U.S. Geological Survey, Denver, CO 80225

${ }^{2}$ University of Texas at San Antonio, TX 78249

${ }^{3}$ National Park Service, Buffalo National River, Harrison AR 72601
}

long corridor (fig. 1) park is managed by the National Park Service with the goals of maintaining water quality and biological diversity within the park. The difficulty of this task is magnified by the potential for multiple contaminant sources, including point and non-point sources, such as a diesel spill along a roadway and increased nitrates from agricultural activities, respectively. Characterization of ground-water flow is necessary to understand which areas may be affected if a contaminant is introduced, and conversely, identification of the source area when contaminants are detected.

Characterization of ground-water flow in the Buffalo National River watershed is complicated due to widespread karst development. Variable dissolution of soluble rock units has produced a number of caves and springs that form complex subsurface networks typical of karst environments. Whereas limits of surface drainages are easily defined using topographic boundaries, recharge basins for karst networks are not necessarily restricted to such boundaries. In these cases, interbasin ground-water flow is observed, increasing the area of potential concern to another drainage basin. Furthermore, flow rates via open conduits in karst terrains can be remarkably high, potentially accommodating rapid transport of contaminants. For example, dye has been documented to have moved greater than 2,000 ft per day (> $600 \mathrm{~m}$ per day) (Mott and others, 1999) within the Buffalo River watershed.

\section{Purpose}

Characterization of ground-water flow through karst aquifers requires a detailed understanding of the geologic features influencing the karst network. Geologic features, such as jointing, faulting, stratigraphic characteristics, and bedding attitudes, can impact the dissolution of soluble rock units, resulting in the development of preferential restricted or enhanced flow paths. To better comprehend the influence on ground-water flow of map-scale geologic features documented in recent geologic mapping by Hudson and Murray (2004) and Hudson and others (2006), a 3D geologic model 


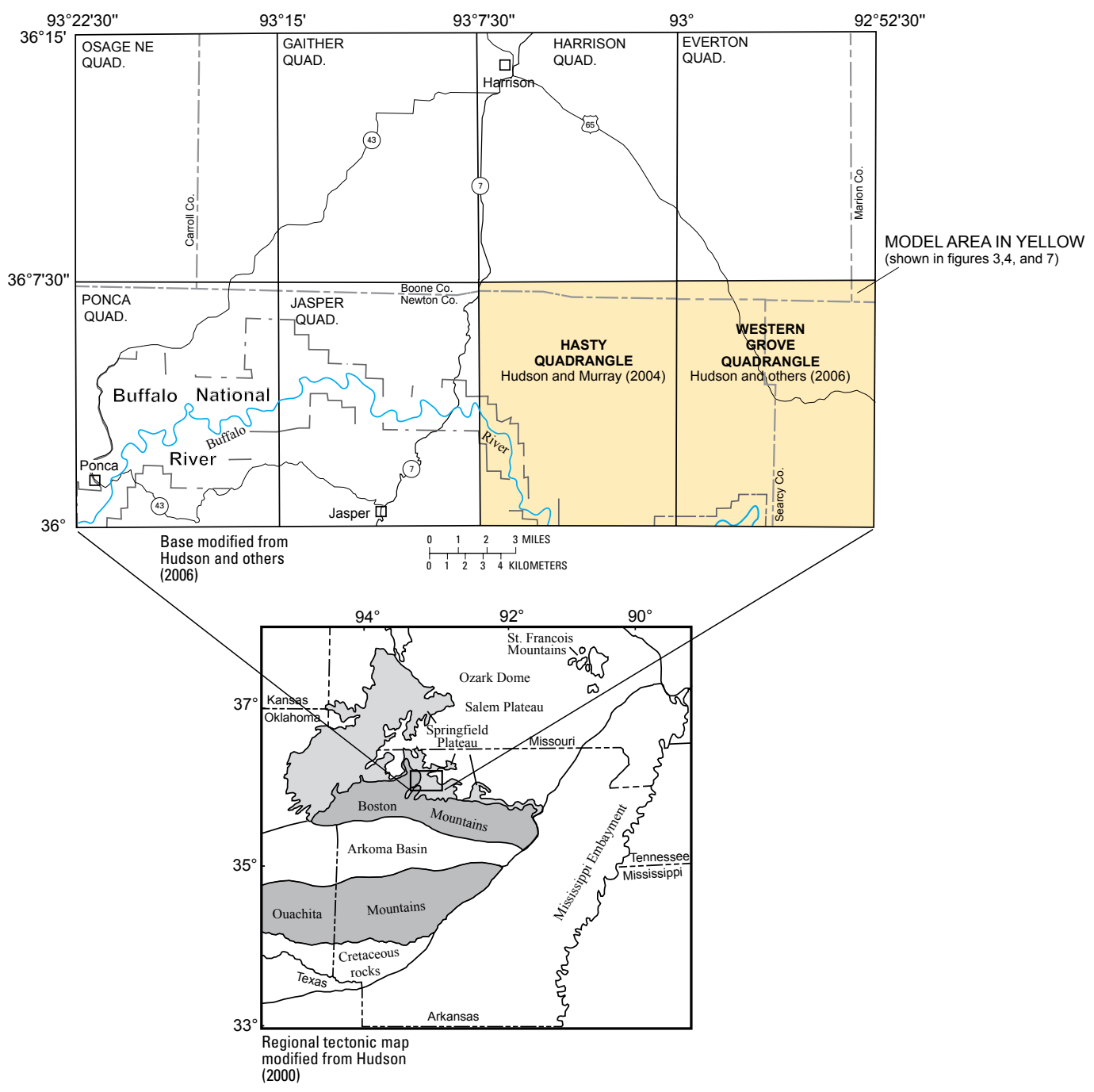

Figure 1. Location of model area in and adjacent to the Buffalo National River in northern Arkansas. Lower regional map illustrates location of the model area relative to other tectonic provinces.

was created for the Davis Creek subbasin encompassing part of the Buffalo River watershed in northern Arkansas. Combined with dye-tracer studies, the model allows visualization of geologic controls on the karst aquifers and provides insight into the possible ground-water pathways.

The model was produced using sophisticated 3D geologic modeling software (EarthVision®; Dynamic Graphics, Inc., Alameda, Calif.) and is accompanied by an interactive viewer allowing the user to explore and manipulate the model in all dimensions. This report also explains the methodology used in constructing the $3 \mathrm{D}$ model and includes all data files used to create the model.

\section{Physiographic Setting}

The Buffalo National River is situated on the southern flank of the Ozark Dome between the Springfield Plateau to the north and the Boston Mountains to the south (fig. 1).
Recent detailed geologic mapping includes a number of 7.5-minute quadrangles encompassing portions of the park and its watershed (fig. 1): Jasper (Hudson and others, 2001), Ponca (Hudson and Murray, 2003), Hasty (Hudson and Murray, 2004) and Western Grove (Hudson and others, 2006). The 3D model covers all of the Western Grove and Hasty quadrangles.

\section{Stratigraphy}

The exposed stratigraphic sequence within the model area contains a $1,560 \mathrm{ft}(470 \mathrm{~m})$ section of sedimentary rocks representing the Ordovician, Mississippian, and Pennsylvanian Systems. The Ordovician lithologies include alternating dolomites, limestones, and carbonate-cemented sandstones with only minor, generally discontinuous, shale beds (Suhm, 1974; Young and others, 1972). Mississippian rocks are represented predominantly by limestones but also by 
significant thicknesses of shale and minor sandstone. The Pennsylvanian rocks are dominantly sandstones and shales with few carbonate lithologies. These beds represent deposition in a series of marine cycles interrupted by periods of erosion or no deposition (Frezon and Glick, 1959). The Cenozoic surficial units are present as colluvial wedges, landslides, and river terraces but they are ignored for the purposes of this model because they are thin and hydrologically insignificant. Figure 2 is a stratigraphic column graphically representing the 17 formations and mappable formational members present in the model area.

The oldest units represented in the model are the Cotter and Powell Dolomites, both of Early Ordovician age. The Cotter Dolomite is not exposed in outcrop within the model area but is identified nearby to the west on the Ponca quadrangle (Hudson and Murray, 2003). The Powell Dolomite conformably overlies the Cotter Dolomite and is exposed in one area along the southern model boundary.

The Middle Ordovician Everton Formation is predominantly composed of dolomites and limestones but also includes sandy carbonate or carbonate-cemented sandstone units. The Everton Formation contains numerous members (Suhm, 1974) but is divided into the lower Everton and upper Everton in this model. The Newton Sandstone Member is the basal unit of the upper Everton Formation and is $10-15 \mathrm{ft}$ (3-4.5 m) thick with well-rounded, fine- to medium-grained quartz arenite.

Younger Ordovician units in the model area include the St. Peter Sandstone and the overlying Plattin and Fernvale Limestones. The Middle Ordovician St. Peter Sandstone is a carbonate-cemented sandstone with lesser siltstone and shale that was deposited in a barrier island environment (Suhm, 1979). The St. Peter Sandstone is the most laterally extensive of the three units and reaches a significant thickness of $100 \mathrm{ft}$ $(30 \mathrm{~m})$ in the southeast part of the Western Grove quadrangle. However, the unit thins to the west and north, where it pinches out just north of the Mill Creek graben. The Middle Ordovician Plattin Limestone is a dense, thinly bedded limestone that reaches a maximum thickness of $70 \mathrm{ft}(21 \mathrm{~m})$ but is only exposed in drainages along the southern border of the model area. The only significant northern extension of the Plattin Limestone in the model area is in the southeast quarter of the Western Grove quadrangle. The Upper Ordovician Fernvale Limestone is a coarsely crystalline, bioclastic limestone that is discontinuous in outcrop with exposures typically less than $10 \mathrm{ft}(3 \mathrm{~m})$ thick.

The Lower and Upper Mississippian Boone Formation unconformably overlies Ordovician rocks and is divided into the basal St. Joe Limestone Member (Kinderhookian to Osagean) and main Boone (Osagean to Meramecian). The St. Joe Limestone is predominantly a chert-free, fossiliferous limestone with a locally preserved thin basal shale and sandstone; the main Boone is a chert-rich, fine- to coarse-grained limestone.

Regression of the shoreline exposed the Boone Formation, resulting in an erosional event. The sea transgressed and deposited the Chesterian Batesville Sandstone and overlying Fayetteville Shale. The Batesville Sandstone is a fine-grained, planar laminated, calcite-cemented sandstone. The Fayetteville Shale consists of a thick sequence of fissile black shales. Shallowing of the sea triggered the deposition of a calcite-cemented sandstone, the Wedington Sandstone Member of the Fayetteville Shale, followed by deposition of the Pitkin Limestone, a micritic, locally oolitic, limestone.

Interbedded shales, siltstones, and sandstones comprising the Lower Pennsylvanian (Morrowan) Cane Hill Member of the Hale Formation were deposited in a near-shore, tidal-flat depositional environment (Wiggins, 1979). Calcite-cemented sandstone of the Morrowan Prairie Grove Member of the Hale Formation was deposited in a shoreface environment.

The Bloyd Formation conformably overlies the Hale Formation and is formally divided into five members farther to the west (Zachry, 1977) but was informally subdivided into an upper and lower interval by Hudson and Murray (2004) and Hudson and others (2006). The lower interval of the Bloyd Formation in the model area is predominantly shale but contains thin beds of sandstone and limestone resulting from open-marine platform deposition. A subsequent regression allowed erosion prior to deposition from terrestrial braided streams forming the middle sandstone of the Bloyd. This sandstone is the basal unit of the upper interval of the Bloyd Formation and it caps the highest topography in the model area.

\section{Structural Geology}

The stratigraphic section within the model area was mildly deformed by faults and folds. The dominant structural feature is the east-west trending graben that extends through the center of the model area (fig. 3). The western extent of the graben, referred to as the Braden Mountain graben by Hudson (1998), is bounded on the north by the St. Joe fault (McKnight, 1935), which is continuous throughout the entire area. The southern boundary is formed by three discontinuous en echelon faults, the easternmost of which is referred to as the Mill Creek fault. The eastern portion of the graben bounded by the St. Joe and Mill Creek faults was designated the Mill Creek graben by McKnight (1935). Observed dips on the north- and south-bounding faults range from $66^{\circ}$ to $88^{\circ}$ and preserved slickensides have steep rake angles, indicating a predominant normal sense of slip. The greatest offset along the Braden Mountain graben is at Braden Mountain and in the drainage to the west. Maximum structural depth is reached in this area and decreases to the west (Hudson and others, 2001), where the Carlton fault zone accommodates some of this offset (Hudson, 2001). A decrease is also observed to the east where the south-bounding fault terminates and overlaps with the next south-bounding fault. Maximum offset along the Mill Creek graben segment is along the easternmost portion of the model area. Throw along the St. Joe fault is as great as 


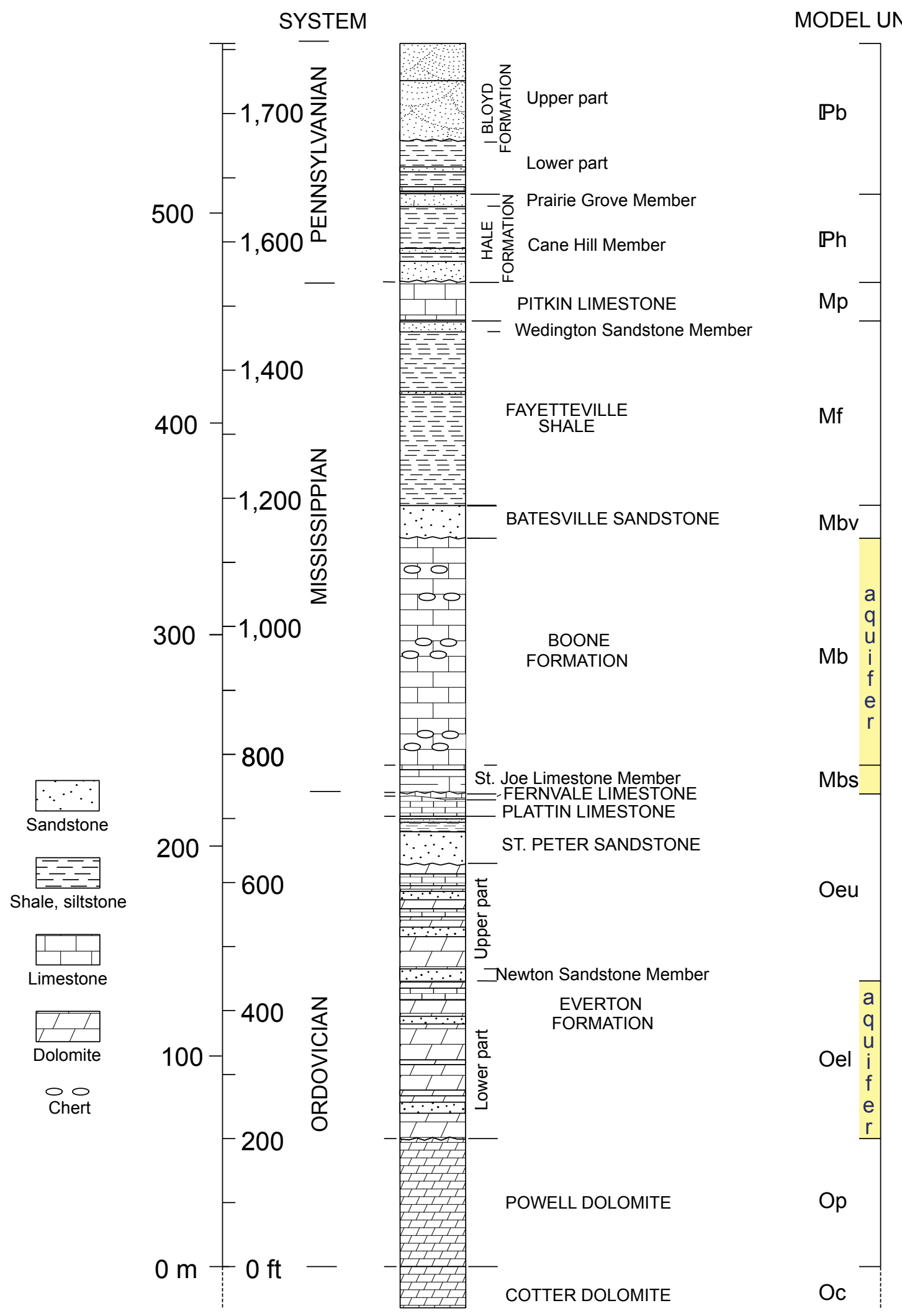

Figure 2. Stratigraphic section showing approximate thickness, lithology, and system of formations within the model area. The exposed lithologies start approximately at the unconformable contact between the Everton Formation and the Powell Dolomite. The aquifers of interest in this report are highlighted in yellow. 


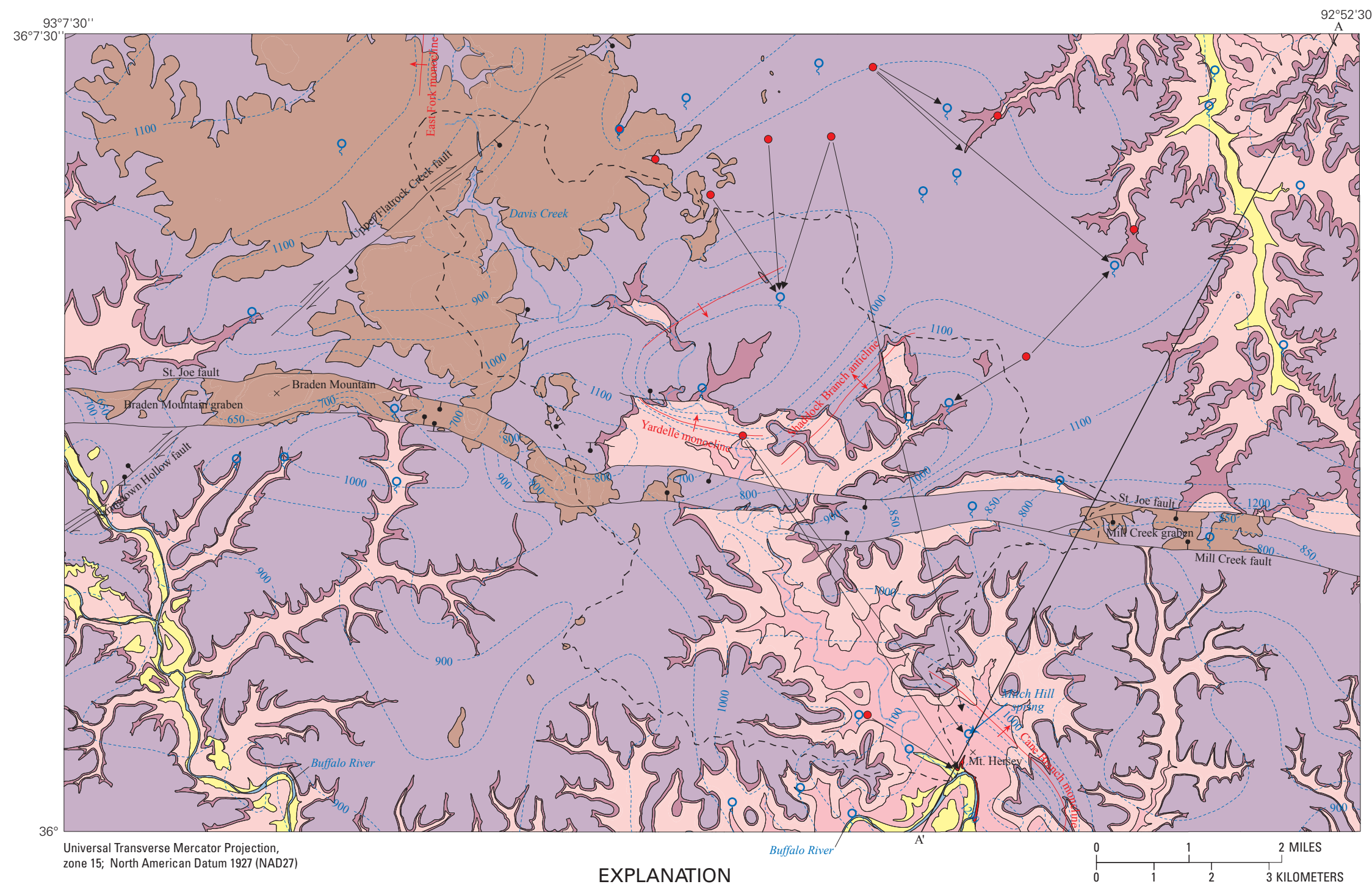

Alluvial and terrace deposits, undivided (Quaternary and T ertiary) $\stackrel{\bullet}{\rightleftharpoons}$ Fault-ball and bar on downthrown side; paired arrows indicate

Post Boone Pennsylvanian-Mississipian rocks

Main body of the Boone Formation (Mississipian)

St. Joe Limestone Member, Boone Formation (Mississipian)

Upper Everton Formation (Ordovician)

relative right-lateral strike-slip movement

$\hat{\imath} \quad$ Anticline

$\uparrow \quad$ Monocline

Structure contours at base of Boone Formation; contour interval $50 \mathrm{ft}$

Lower Everton Formation (Ordovician)

Powell Dolomite (Ordovician)

$\rightarrow \quad$ Indicates where dye originated and points to detection site

- - Davis Creek surface watershed topographic boundary

Cross-section line (shown in detail in fig. 7)

? Spring location

- Dye injection site 
Figure 3. (preceding page) Area map showing generalized geology, structure contours, structural features, Davis Creek watershed, and key geographic features (geology from Hudson and Murray (2004) and Hudson and others (2006)).

$400 \mathrm{ft}(122 \mathrm{~m})$ and for the Mill Creek fault as great as $250 \mathrm{ft}$ (76 m).

The northeast-striking Stringtown Hollow and Upper Flatrock Creek faults (fig. 3) have throws that are down-tothe-northwest and -southeast, respectively. By analogy with other northeast-striking faults in the region, it is likely that these faults also have components of right-lateral strike-slip movement in addition to vertical movement (Hudson and Murray, 2004).

Structure contours for the base of the Boone Formation (Hudson and Murray, 2004; Hudson and others, 2006), including the basal St. Joe Limestone Member, illustrate additional folds in the form of monoclines and one anticline (fig. 3). Figure 4 more graphically demonstrates folding in the top of the modeled Cotter Dolomite horizon. The Cotter Dolomite was chosen because it is the horizon least dissected by topography and it most effectively illustrates the structural features present in the younger horizons.

The Yardelle monocline in the central part of the model area is expressed by consistent north to north-northeast dips of typically $5-15^{\circ}$. North of the Yardelle monocline, a northeast-trending monocline has less throw to the southeast but does expose upper Everton Formation along Davis Creek (fig. 3). Most folding in the area is expressed as monoclines; however, both limbs of the northeast-trending Shaddock Branch anticline have significant dip (fig. 4). The southwestern extension of the Shaddock Branch anticline and the eastern extension of the Yardelle monocline merge and combine to expose lower Everton Formation along Davis Creek just north of the St. Joe fault (fig. 3). The north-trending East Fork monocline is west-dipping and continues farther north of the northern edge of the model area for at least $2 \mathrm{mi}$ (3.2 km) (Hudson, 1998).

The most significant fold within the model area is the northwest-trending Cane Branch monocline along the southern boundary (figs. 3 and 4). This northeast-dipping monocline has about $300 \mathrm{ft}(91 \mathrm{~m})$ of structural relief and brings the base of the Boone Formation to the highest elevation in the model area (Hudson and others, 2006). The Powell Dolomite is exposed just south of Mt. Hersey as a result of erosion through this structural high by the Buffalo River (fig. 3).

It is likely that deformation within the model area developed in late Paleozoic time in response to the Ouachita orogeny to the south. The east-west-trending normal faults and the northeast-trending oblique faults are consistent with north-south extension accompanied by east-west shortening. This east-west shortening may have been accommodated by the generally northerly trending monoclines and anticline. Hudson (2000) suggested that this deformation was related to flexure in the foreland of the Ouachita orogenic belt in Early to Middle Pennsylvanian time.

\section{Model Units}

Not all of the 17 formations or members in figure 2 were included as individual zones in the 3D model. Formations or members were combined into model units based on three main criteria: (1) similar hydrologic properties directly related to lithology, (2) lateral discontinuity, and (3) similar age, which in most cases consisted of formational members. Figure 2 summarizes the combination of the units for the 11 modeled zones. Most zones are modeled based on surface contacts from Hudson and Murray (2004) and Hudson and others (2006). The Cotter and Powell Dolomites and the St. Joe Limestone Member of the Boone were modeled at a constant thickness, which are indicated in the following discussion.

The Cotter and Powell Dolomites are both modeled as individual zones. The Cotter Dolomite is not exposed at the surface but is included to establish a model base. As modeled herein, the Cotter Dolomite represents the top of an undivided section of Lower Ordovician and Cambrian units and therefore does not represent a true total thickness. The Powell Dolomite is argillaceous dolostone that is less susceptible to dissolution than pure dolomite due to its clay content. It appears to behave as a lower confining unit to the overlying Everton Formation based on spring locations at the upper contact of the Powell Dolomite and overlying Everton Formation. The Powell is modeled with a constant thickness of $200 \mathrm{ft}$ (61 m) taken from a fully exposed section in the Ponca quadrangle to the west (Hudson and Murray, 2004).

The Everton Formation is divided into two modeled zones at the basal contact of the Newton Sandstone Member. The lower Everton Formation is considered to host one of the two major karst aquifers in the area (Hudson and others, 2005). This designation is based on spring locations and on a losing reach of Davis Creek coinciding with exposure of the lower part of the Everton Formation. Collapse breccias are preserved in lower intervals of the lower Everton Formation, providing further evidence for an extensive karst network. The overlying Ordovician units of the St. Peter Sandstone and Plattin and Fernvale Limestones have been combined with the upper part of the Everton Formation in the model. The upper part of the Everton contains limestone and dolostone that are susceptible to dissolution and cave development. However, the upper part of the St. Peter Sandstone contains significant sandstone, siltstone and shale; spring localities are less common in this model unit.

The Mississippian Boone Formation hosts the dominant karst aquifer in the model area. It is divided into two modeled zones, the St. Joe Limestone Member and the overlying main Boone. The basal modeled contact for the St. Joe Limestone Member is derived from mapped contacts and structure 


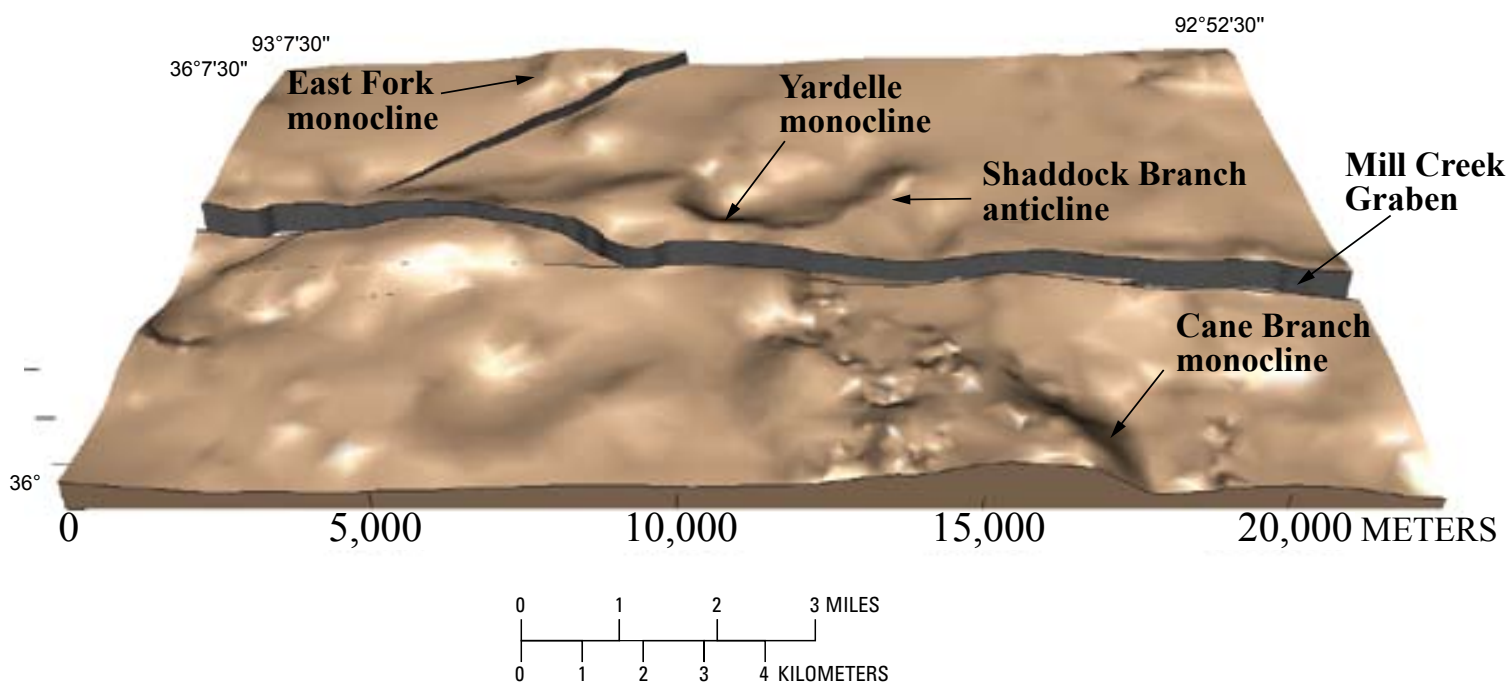

Figure 4. Expression of structural features in the modeled Cotter Dolomite horizon. Gray area through the center of the image is the down-dropped Mill Creek graben. View is looking directly north. Values along front edge of image are in meters but the scale varies to the north. Vertical exaggeration is about $2 \mathrm{X}$.

contours from Hudson and Murray (2004) and Hudson and others (2006). The upper contact is modeled based on a constant $50 \mathrm{ft}(15 \mathrm{~m})$ thickness which was determined to be reasonable from field investigations. The more massively bedded main Boone is similar in hydraulic conductivity to the St. Joe and contains abundant karst features. A number of caves have developed in the main Boone Formation, including commercially operated caves, and the largest documented cave in Arkansas, Fitton Cave, located to the west in the Jasper and Ponca quadrangles. The upper model contact is based on both field contacts and points interpreted from structure contours that assume a thickness of $350 \mathrm{ft}(106 \mathrm{~m})$ above the upper contact of the St. Joe.

The Batesville Sandstone is a fine- to very fine-grained sandstone that is occasionally calcite-cemented and it overlies the Boone Formation. Outcrops of the sandstone are not laterally continuous except in the northwest quarter of the model area; therefore, they have only minor influences on the ground-water transport. The upper contact is modeled using a constant thickness of $65 \mathrm{ft}(19 \mathrm{~m})$ above the basal contact with the Boone Formation.

The Fayetteville Shale zone constitutes both the Wedington Sandstone Member and the main body of the formation. The model unit is predicted to have a low conductivity as a result of the thick shale interval. Additionally, the lateral extent of the Fayetteville Shale is isolated to the northwestern quarter of the model area. The overlying Pitkin Limestone is highly susceptible to dissolution and therefore karst formation, but it is limited in extent to a few perched outcrops in the northwestern quarter of the model area.

The Pennsylvanian Hale Formation is modeled as one zone. The Cane Hill Member, comprised of some basal sandstones and alternating shales, siltstones, and thin sandstone layers, is significantly different from the calcite-cemented sandstone of the overlying Prairie Grove Member. The Cane Hill Member has low hydraulic conductivity, as would be expected for shale. In contrast, the thin Prairie Grove Member does demonstrate signs of dissolution and therefore can have a significantly higher hydraulic conductivity than that of the Cane Hill. However, because the lateral extent of the Hale Formation is limited and does not significantly influence the major karst aquifers, the two members are modeled as a single zone.

The modeled stratigraphic section is completed by the Bloyd Formation represented as a single zone. The lower part of the Bloyd is composed dominantly of shale with few sandstone and limestone layers and has a low hydraulic conductivity. The overlying upper part of the Bloyd Formation is marked by a basal, silica-cemented, fine-grained sandstone up to $60 \mathrm{ft}$ thick $(18 \mathrm{~m})$. The Bloyd Formation is laterally insignificant and has little influence on the ground-water transport in the model area because it is largely eroded.

\section{Ground-Water Hydrology}

In addition to stratigraphic control, structural features, such as faulting and folding, can strongly influence recharge, flow, and discharge of the ground water. Fractures associated with faulting can increase flow, thereby increasing dissolution. Faults can juxtapose units of variable permeabilities, establishing either a barrier diverting flow or a more permeable layer channeling the flow. In the study area, the central graben system has significant offset and juxtaposes units with contrasting hydrologic properties. For example, significant offset is observed where Davis Creek crosses the down-dropped 
graben, placing the lower Everton Formation-hosted aquifer laterally adjacent to the upper Boone-hosted aquifer.

Structural highs and lows within the model area are formed by folding and faulting. Structural lows act to localize spring discharge in the Boone-hosted aquifer (Mott and others, 1999), which is perched above the current Buffalo River in the Davis Creek area. The Boone Formation is extensively exposed at the surface so precipitation and infiltration contribute to recharge. In contrast, exposures of the lower aquifer are generally restricted to deeply incised channels, which limit recharge. It is likely that recharge and discharge of the Everton-hosted lower aquifer would also be controlled by structural highs similar to those in the upper aquifer (Hudson and others, 2005).

Most major springs discharge from the upper aquifer but the largest spring, Mitch Hill Spring, discharges from the lower aquifer (fig. 5). Recent dye-tracing studies conducted by the National Park Service have identified a component of interbasin recharge from local springs in the upper reaches of the Davis Creek subbasin (fig. 5) (National Park Service, written commun., 2004). The three springs identified as drawing flow from the Crooked Creek watershed adjacent to the north are the Yardelle, Yardelle Branch, and Shaddock Branch springs. Discharge from the Yardelle and Yardelle Branch springs is transported as surface flow across the upper Everton Formation until it reaches a losing section of the Davis Creek coincident with exposure of the lower Everton Formation. The Yardelle monocline and the Shaddock Branch anticline merge in this area to form a significant structural high, bringing the lower Everton Formation to the surface (Hudson and others, 2006) supplying a localized area for recharge.

Discharge from Mitch Hill Spring further demonstrates the control of structural highs on discharge from the lower aquifer. Erosion through the Cane Branch monocline by the Buffalo River has exposed the Powell Dolomite below the lower Everton Formation (fig. 3). Mitch Hill Spring is located near the base of the lower aquifer, approximately 10 $\mathrm{ft}(3 \mathrm{~m})$ above the contact with the Powell. The underlying Powell Dolomite is argillaceous dolostone that behaves as a lower confining layer, forcing the spring to discharge.

\section{Sources of Data for 3D Model}

The model was created using surface-contact, faulttrace, and interpretive data derived from structure contours from Hudson and Murray (2004) and Hudson and others (2006). Control points were gathered during field mapping using global positioning system (GPS), barometric altimeter, and topographic maps to attain an accuracy of generally less than $65 \mathrm{ft}(20 \mathrm{~m})$ horizontal and $20 \mathrm{ft}(6 \mathrm{~m})$ vertical. Additional points were extracted from interpreted contacts and fault traces, which were constrained by the control points.
Structure contours for the base of the Boone Formation (base of the St. Joe Limestone Member) were the only source of subsurface data available and represent the authors' interpretation. Additional subsurface model data points were generated for the top of the St. Joe Limestone Member by adding $50 \mathrm{ft}(15 \mathrm{~m})$ and the top of the main Boone Formation by adding $400 \mathrm{ft}(122 \mathrm{~m})$ to the elevation of the original structure contour (50 ft for the modeled thickness of the St. Joe; $350 \mathrm{ft}$ for the thickness of the main Boone). The main Boone was not modeled as a constant thickness but this internal control was found necessary to allow the monoclines and anticline to be modeled correctly.

\section{Modeling Methodology}

Scattered data files were input into the software as text files containing $\mathrm{x}, \mathrm{y}$, and $\mathrm{z}$ values or longitude, latitude, and elevation, respectively. The horizontal data were projected into Universal Transverse Mercator (UTM) using the North American Datum of 1927 (NAD 27), resulting in x and y values in meters. Vertical units of feet were used based primarily on user preference but also allowed for easier quality checks with USGS topographic maps and pre-published geologic maps that use feet for elevation. The $\mathrm{x}, \mathrm{y}$, and $\mathrm{z}$ values were generated for these data in the Geographic Information System (GIS) by converting linear formational contacts and fault traces into point data based on vertices locations. Elevation values for contacts and faults were attained by intersecting the points with USGS Digital Elevation Models (DEM) with $10 \mathrm{~m}$ resolution data representing the present topography. The resulting data files are specific to the top boundary of each stratigraphic unit included in the model (Appendix A).

The upper Everton Formation horizon was designated as a reference layer for the model because of an abundance of control points and the authors' original structure contours. The reference layer controls computation of all other intermediate horizons assigned to reference that layer.

Model faults were constructed using scattered data representing the fault trace. Fault dip and dip-azimuth values were assigned to their respective faults, allowing EarthVision ${ }^{\circledR}$ to generate the 3D fault surfaces. Fault dip values were based on measured values where available. However, limited exposure of the faults required some averaged values to be assigned to the two eastern-most, south-bounding faults along the graben.

\section{Evaluation of Model Results}

The first method of evaluating the 3D model was based on visual comparison with published maps for the model area. 


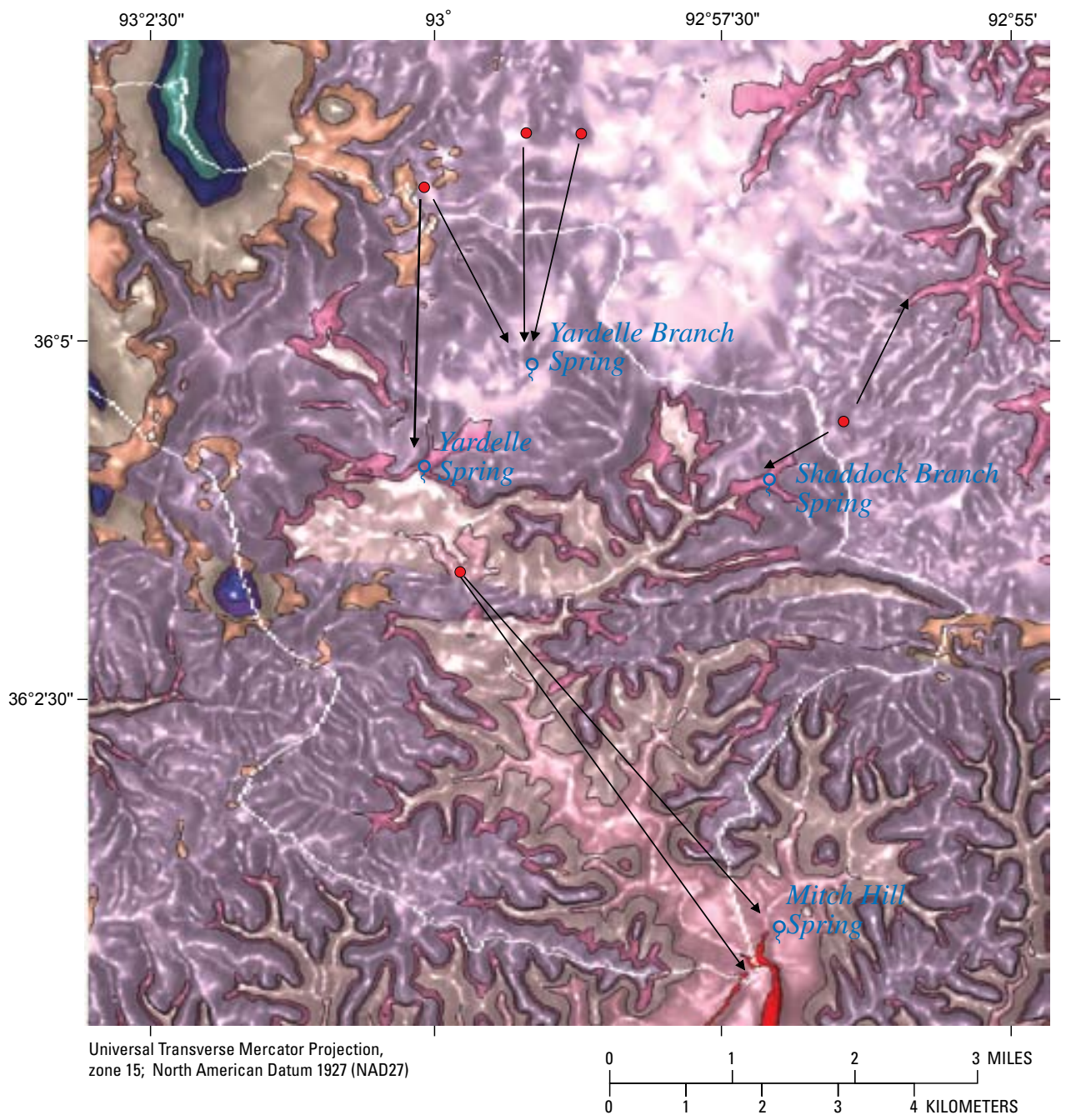

Figure 5. Portion of the Davis Creek subbasin. The white line represents the surface watershed topographic boundary. Symbology for dye injection sites and spring/dye receptor sites follows that described in fig. 3. Arrows point from input to discharge locations. Geology from 3D model, as in fig. 6.

Control on the 3D model was largely based on surface data from these maps. Therefore, few discrepancies were expected on the model surface. Some zones were modeled based on a constant thickness, such as the St. Joe Limestone Member and Batesville Sandstone, introducing a possibility for error. A second method of evaluation was comparison with cross sections generated by Hudson and Murray (2004) and Hudson and others (2006). Because there was no subsurface data available, the published cross-sections were considered the control.

Inspection of the model surface indicated close comparison with the published maps, but discrepancies were present. For example, figure 6 shows a vertical view of the modeled geologic surface in comparison with the published geology. Of particular interest to the Davis Creek study, an exposure of lower Everton Formation was modeled in the area where Davis Creek crosses the graben (white arrows, figure 6). These exposures were not documented in the original mapping but these outcrops are small and could have been covered by thin layers of surficial deposits. Outside of the Davis Creek subbasin there are several other areas that deviate from the original mapping. These areas are generally centered around the graben and are presumably related to slight changes in dip related to faulting.

Comparison with the cross-sections demonstrates accurate subsurface zone modeling. Figures $7 A$ and $B$ illustrate a published cross-section for the Western Grove quadrangle (Hudson and others, 2006) and the cross-section generated for the model, respectively. Similar thicknesses and offsets from faulting are observed in both, suggesting the model was accurately extrapolated in the subsurface from the surface mapping. 

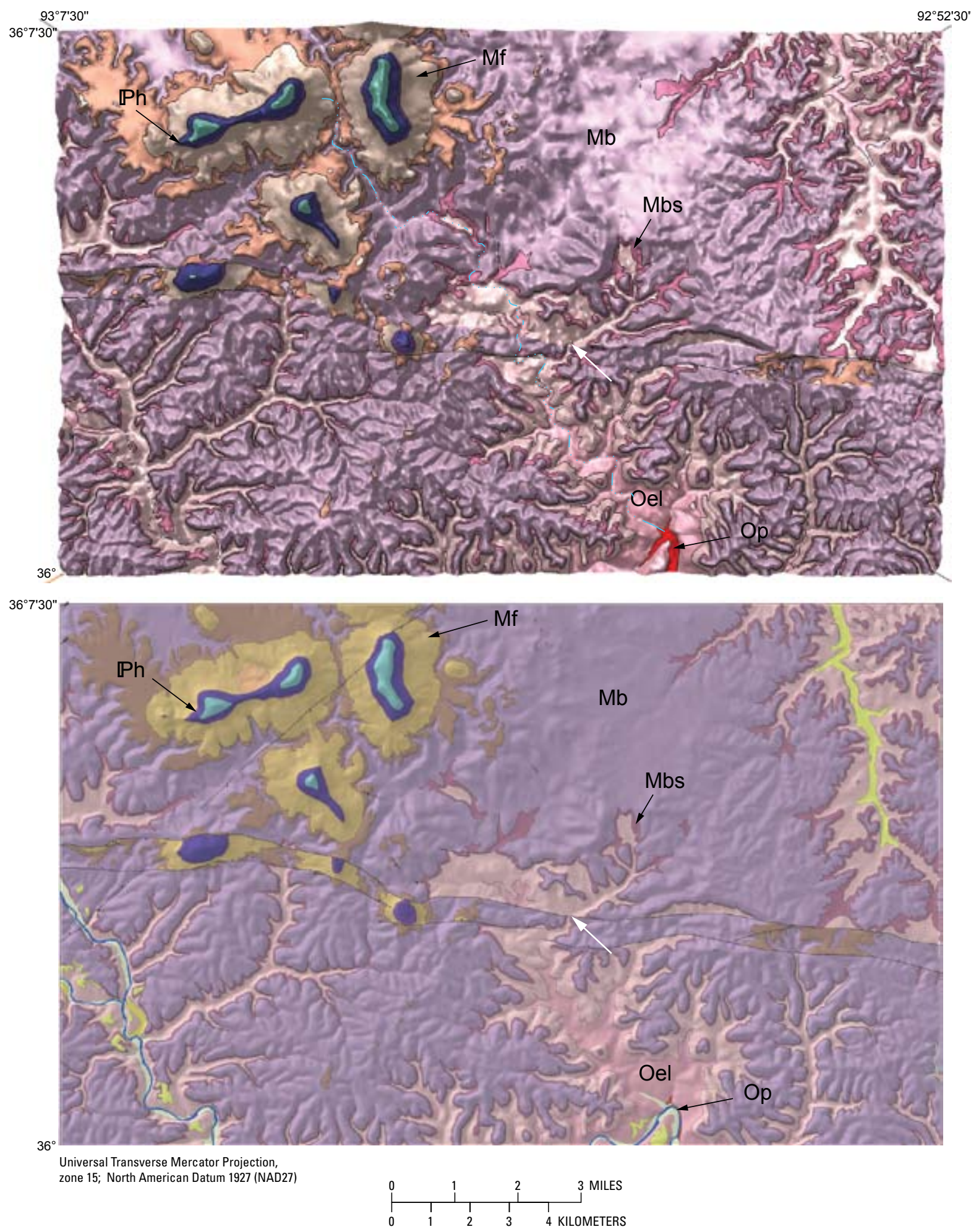

Figure 6. Comparison of geology from the 3D model (top) and published mapping (bottom) by Hudson and Murray (2004) and Hudson and others (2006). White arrows indicate an area where the modeled geology differs from the published geology and is discussed in the text. Published mapping includes surficial units whereas the image from the model does not. Definition of unit abbreviations and colors follows those used in figs. 2 and 3. 


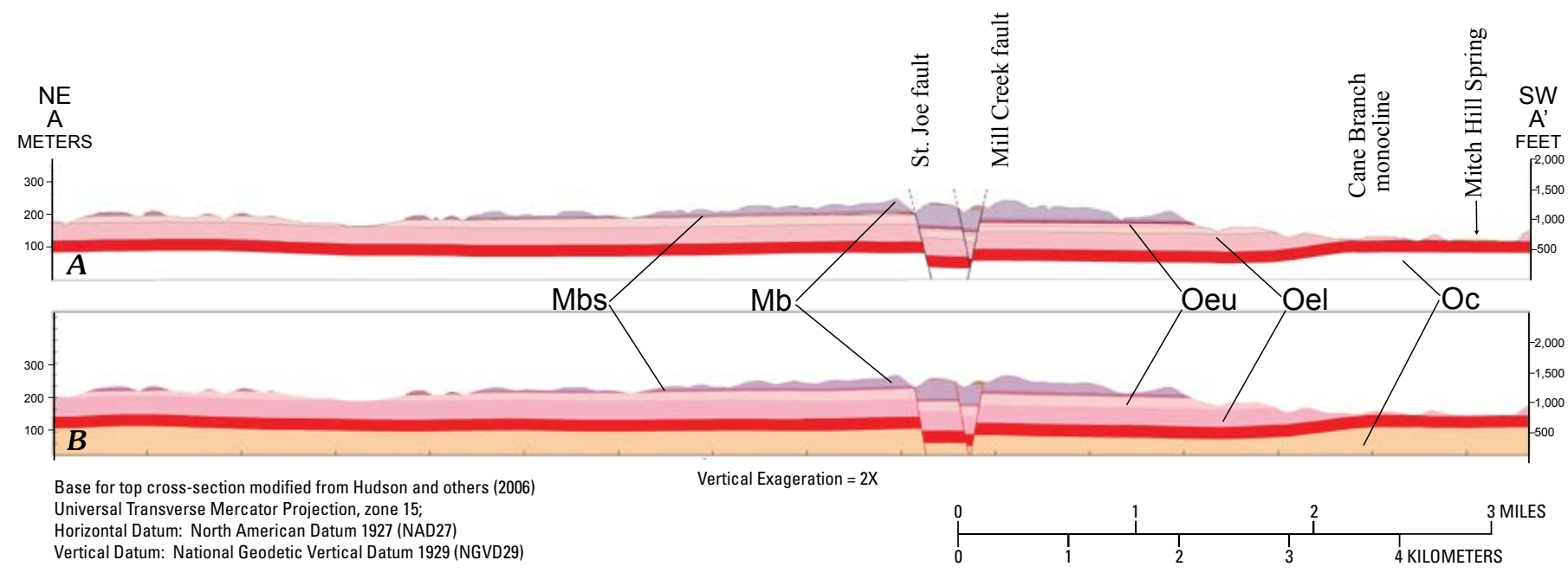

Figure 7. Cross-section comparison between $A$ (top), published Western Grove cross-section from Hudson and others (2006), and $B$ (bottom), cross-section generated from the $3 \mathrm{D}$ model. For definition of map-unit symbols see fig. 2. No color represents the Cotter Dolomite in the top cross-section because Hudson and others (2006) did not include it.

\section{Conclusions}

Visualization of a 3D geologic framework that hosts karst networks can contribute to better water resource management. Although detailed flow paths in karst networks can be unpredictable, general concepts, such as a down-gradient flow path, can be easily evaluated with an accurate 3D geologic model. Incorporation of detailed dye-tracer studies can lead to a better understanding of these flow paths and allow improved prediction of point-source input and output. Furthermore, prior preparation of a 3D model could enhance effective planning of a dye-tracer study.

This study illustrates that an accurate 3D geologic model can be constructed primarily from surface contact data for relatively simple "layer-cake" geology that is largely dissected by topography. Some subsurface data would be useful, however, to make subsurface faulting and folding more reality-based. Structure contours were used in this case to allow the authors' interpretation to exert greater influence on the model. Areas of more complex structure would likely require significantly more subsurface data to control folding and faulting not observed at the surface, but it is apparent that significant control is gained by using surface contacts and structure contours.

\section{References Cited}

Frezon, S.E., and Glick, E.E., 1959, Pre-Atoka rocks of northern Arkansas: U.S. Geological Survey Professional Paper 314-H, $18 \mathrm{p}$.
Hudson, M.R., 1998, Geologic map of parts of the Gaither, Hasty, Harrison, Jasper, and Ponca quadrangles, Boone and Newton Counties, northern Arkansas: U.S. Geological Survey Open-File Report 98-116, scale 1:24,000.

Hudson, M.R., 2000, Coordinated strike-slip and normal faulting in the southern Ozark dome of northern Arkansas-Deformation in a late Paleozoic foreland: Geology, v. 28, no. 6, p. 511-514.

Hudson, M.R., Mott, D.N., Turner, K.J., and Murray, K.E., 2005, Geologic controls on a transition between karst aquifers at Buffalo National River, northern Arkansas [abs.], in Kuniansky, E.L., ed., U.S. Geological Survey Karst Interest Group Proceedings, Rapid City, S. Dak., September 12-15, 2005: U.S. Geological Survey Scientific Investigations Report 2005-5160, p. 143.

Hudson, M.R., and Murray, K.E., 2003, Geologic map of the Ponca quadrangle, Newton, Boone, and Carroll Counties, Arkansas: U.S. Geological Survey Miscellaneous Field Studies Map MF-2412, scale 1:24,000.

Hudson, M.R., and Murray, K.E., 2004, Geologic map of the Hasty quadrangle, Boone and Newton Counties, Arkansas: U.S. Geological Survey Scientific Investigations Map SIM 2847, scale 1:24,000.

Hudson, M.R., Murray, K.E., and Pezzutti, Deborah, 2001, Geologic map of the Jasper quadrangle, Newton and Boone Counties, Arkansas: U.S. Geological Survey Miscellaneous Field Studies Map MF-2356, scale 1:24,000. 
Hudson, M.R., Turner, K.J., and Repetski, J.E., 2006, Geologic map of the Western Grove quadrangle, northwestern Arkansas: U.S. Geological Survey Scientific Investigations Map SIM 2921, scale 1:24,000.

McKnight, E.T., 1935, Zinc and lead deposits of northern Arkansas: U.S. Geological Survey Bulletin 853, 311 p.

Mott, D.N., Hudson, M.R., and Aley, Tom, 1999, Nutrient loads traced to interbasin groundwater transport at Buffalo National River, Arkansas, in Harmon, D., ed., Proceedings of the 10th Conference on Research and Resource Management in Parks and Public Lands: Hancock, Mich., George Wright Society, p. 114-121.

Pantea, M.P., and Cole, J.C., 2004, Three-dimensional geologic framework modeling of faulted hydrostratigraphic units within the Edwards Aquifer, northern Bexar County, Texas: U.S. Geological Survey Scientific Investigations Report 2004-5226.

Suhm, R.W., 1974, Stratigraphy of Everton Formation (Early Medial Ordovician), northern Arkansas: AAPG Bulletin, v. 58 , no. 4 , p. 685-707.
Suhm, R.W., 1979, Depositional history of Everton and St. Peter Formations (Middle Ordovician) in Arkansas: Geological Society of America Abstracts with Programs, v. 11, no. 2, p. 167.

Wiggins, D.W., 1979, Sedimentary environments of the Hale Formation (Morrowan), Madison County, northwest Arkansas: Geological Society of America Abstracts with Programs, v. 11, no. 2, p. 167.

Young, L.M., Fiddler, L.C., and Jones, R.W., 1972, Carbonate facies in Ordovician of northern Arkansas: AAPG Bulletin, v. 56 , no. 1 , p. $68-80$.

Zachry, D.L., 1977, Stratigraphy of middle and upper Bloyd strata (Pennsylvanian, Morrowan), northwestern Arkansas in Sutherland, P.K., and Manger, W.L., eds., Upper Chesterian-Morrowan stratigraphy and the Mississippian-Pennsylvanian boundary in northeastern Oklahoma and northwestern Arkansas: Oklahoma Geological Survey Guidebook 18, p. 61-66. 